\section{THE RELATIONSHIP BETWEEN BUDDHISM AND INDIGENOUS BELIEFS AND PEOPLE AS REFLECTED IN THE NAMES OF LOKAPĀLAS IN EARLY BUDDHIST LITERATURE $^{1}$}

\section{Natchapol Sirisawad ${ }^{2}$}

\section{บทคัดย่อ}

บทความนี้มุ่งศึกษาวิเคราะห์ความสัมพันธ์ระหว่าง พุทธศาสนากับความเชื่อดั้งเดิมและชนพื้นเมือง ดั้งเดิม ที่สะท้อนผ่านชื่อของโลกบาลในวรรณคดี พุทธศาสนา โดยเฉพาะอย่างยิ่งท้าวธตรฐ ท้าว วิรุพหก และท้าววิรูปักข์ ผลการศึกษาพบว่า พุทธ ศาสนามีความความพยายามในการรวมความเชื่อ ดั้งเดิมหรือชนพื้นเมืองดั้งเดิมซึ่งปรากฏมาแล้ว ตั้งแต่ก่อนหรือร่วมสมัยกับพุทธกาลให้เข้ามาอยู่ ภายใต้พุทธศาสนาดังจะเห็นจากรายนามของ โลกบาลที่อาจสะท้อนร่องรอยของความเชื่อดั้งเดิม และชนพื้นเมืองดั้งเดิมที่ได้เปลี่ยนฐานะให้

1 ความสัมพันธ์ระหว่างพุทธศาสนากับความเชื่อดั้งเดิมและชน พื้นเมืองดั้งเดิมที่สะท้อนผ่านรายนามของโลกบาลในวรรณคดี พุทธศาสนายุคต้น

2 (ณัชพล ศิริสวัสดิ์) Lecturer from the Department of Eastern Languages (South Asian Languages) Faculty of Arts, Chulalongkorn University and Ph.D. Candidate in the Doctoral Program in Buddhist Studies at the Ludwig-MaximiliansUniversität, Germany, E-mail: sg 25102@hotmail.com
กลายเป็นเทวดาในความเชื่อทางพุทธศาสนา และ การกำหนดให้โลกบาลดังกล่าวเป็นหัวหน้าของ เหล่าคนธรรพ์ กุมภัณฑ์ นาค เพื่อแสดงการยอมรับ ความเชื่อดั้งเดิมในการนับถือนาค ความเชื่อเรื่อง วิญญาณบรรพบุรุษ ความเชื่อเกี่ยวกับความตายและ การกลับฟื้นคืนชีพ ความเชื่อดั้งเดิมของชาวอารยัน หรือกลุ่มชนพื้นเมืองดั้งเดิมที่เป็นเผ่านาค

\section{Abstract}

The purpose of this article is to analyze aspects of the relationship between Buddhism, indigenous beliefs and people through the names of lokapālas in early Buddhist literature, and especially the names of the three great kings, Dhatarattha, Virülha (or Virūlhaka), and Virūpakkha. The study revealed that the name of the three great kings, Dhatarattha, Virülha (or Virülhaka), and Virüpakkha, may reflect traces of earlier or contemporaneous indigenous beliefs and people who had cultural encounters with Buddhism. The indigenous beliefs consist of the nāga cult, belief in spirits, early practice of urn-burials and belief in the soul or spirit of the dead rising from the grave, primitive beliefs of Aryan people and, nāga as a tribe. Buddhism shows an attempt to incorporate these beliefs and people into the Buddhist cosmology by elevating some local gods, indigenous beliefs and tribal people to divine status, such as lokapālas, who become chieftains of the gandhabbas, the 
nāgas, and the kumbhandas, in order to show acceptance of earlier or contemporaneous indigenous beliefs and tribes. These findings may help to improve understanding more of the sociology of early Buddhism.

\section{Introduction}

Scholars disagree about the nature of the lokapālas in early Buddhist literature. According to T.W. Rhys Davids and William Stede (1921-5: 568-569), the Four Great Kings are classified in a smaller, autocratic state, a chieftain, prince, ruler, usually (collectively) as a group; in addition, G.P. Malalasekera ([1938], Reprint. 2007: 958) states that the assembly between the Four Regent Devas with their followers and Sakka in the Sudhammā-sabhā are similar to the assembly of the tribal community, especially the Kosala-clan. M.M.J. Marasinghe (1974: 71) suggests that the tribal leader is already quite similar to the tribal god. The norms of conduct required for elevation to celestial status in early tribal societies would naturally have helped in the deification of the tribal leaders themselves. The transition from human to divine status would hardly have been difficult or distinct, as in these early tribal stages the line of demarcation between tribal leader and tribal god would not have been very distinct. According to various scholars, the names of the Four Great Kings may reflect indigenous beliefs and social groups in early Buddhism since the names of these gods, except Kuvera, are not found in Sanskrit literature, but are found particularly in early Pali and Buddhist Sanskrit scriptures.

\section{The Buddhist Lokapālas: an Overview}

The "lokapālas" (Guardians of the World) or "Mahārājas" (Great Kings) of Buddhist mythology are four in number: Dhataratțha (Skt. Dhṛtarāșțra), Virūḷha or Virūḷhaka (Skt. Virūọhaka), Virūpakkha (Skt. Virūpākșa), and Kuvera or Vessavaṇa (Skt. Kubera or Vāiśravaṇa). The four kings feature frequently in the early texts, particularly in the Dīgha-nikāya, but seem to recede into the distance in the later canonical literature. They are individually, and anthropomorphically, described with some frequency in several suttas of the Dīgha-nikāya. The Ātānātịya Sutta (D. III, pp. 203 f.) and the Mahāsamaya Sutta (D. II, pp. 257 f.), for instance, give vivid accounts of each of them, the former giving a commentary on the four. Both these suttas depict them as non-human beings (amanussa), paying homage to the Buddha Gotama. They give the classes of non-human beings over whom the four hold sway: Dhatarattha, ruler of the east, is lord (adhipati) of the gandhabbas; Virūlna, ruler of the south, where they whom men call peta-folk reside, is lord of the kumbhandas; Virūpakkha, ruler of the west, is lord of the nāgas and Kuvera, whose identity with Vessavana is established in the Āṭānātiya Sutta (D. III, p. 201), is ruler of the north and lord of the yakkhas. The Āțānātiyya Sutta, which along with the other suttas mentioned, states that the four Great Kings were devotees of Gotama and of the seven Buddhas, also has a very curious and interesting passage, in which the four Great Kings are described as great yakkhas who are protectors of the followers of the Buddha 
from fear of the yakkhas. (Bandula Jayawardhana,1971: 707) They rule over four horizontal direction of the world as viewed from Meru mount at the center. Their habitation is Cātummahārājikā, the heavenly realm of the Four Great Kings, classified in the world of sense-desire (Kāmabhūmi). Consequently, the hosts of these Great Kings who also dwell in this realm are called cātummahārājikā deva, or devas of the Cātummahārājika.

\section{Traces of Indigenous Beliefs and Social Groups as Reflected in the Names of Lokapālas: Virüpakkha, Dhataraț̣ha and Virūlhaka}

J.P. Vogel ([1926], Reprint. 1972: 9) surmised that the idea of four or six dragons guarding the corners of the world is more primitive than that of the anthropomorphic lokapālas. Quite possibly both the system of the guardian-gods and that of the elephants of the quarters (dinnāga) are ultimately derived from the notion of the dragons of the sky which must have still been alive in the early period when the hymns of the Atharvaveda were composed. This idea can be applied to concepts of lokapālas in Buddhist literature because not only are mighty deities mentioned as lord (adhipati) of the directions, but poisonous serpents are also mentioned as warders or guardians in the Vedic period as seen in the Black Yajurveda or Täittirìya Samhitā (TS. 5.5.10.1-2) and Atharva-veda (AV. 3.27.1-6)

In a hymn of the Black Yajurveda (TS. 5.5.10.1-2), paying homage to the gods of the quarters, for each of the divine regents, another supernatural being is invoked as the warder or protector of the region.

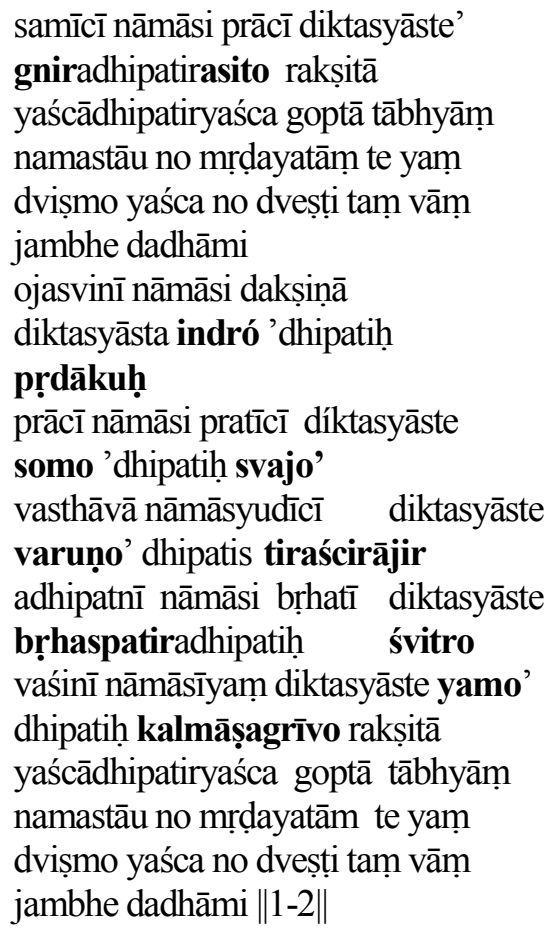

Thou art the eastern quarter, the favorable by name; of thee as such Agni is the overlord, the black (snake) the guardian; the overlord and the guardian, to them homage; may they be gentle to us; him whom we hate and who hate us I place within the jaws of you two. Thou art the southern quarter, the mighty by name; of thee as such Indra is the overlord, the scorpion the guardian; the overlord and the guardian, 
to them homage; may they be gentle to us; him whom we hate and who hate us I place within the jaws of you two.

Thou art the western quarter, the forward by name; of thee as such Soma is the overlord, the viper the guardian; the overlord and the guardian, to them homage; may they be gentle to us; him whom we hate and who hate us I place within the jaws of you two. Thou art the northern quarter, the stable by name; of thee as such Varuna is overlord, the striped snake the guardian; the overlord and the guardian, to them homage; may they be gentle to us; him whom we hate and who hate us I place within the jaws of you two. Thou art the great quarter, the lady paramount by name; of thee as such Brihaspati is overlord, the white the guardian; the overlord and the guardian, to them homage; may they be gentle to us; him whom we hate and who hate us I place within the jaws of you two.

Thou art this quarter, the powerful by name; of thee as such Yama is the overlord, the spotted necked (snake) the guardian; the overlord and the guardian, to them homage; may they be gentle to us; him whom we hate and who hate us I place within the jaws of you two.

(A. B. Keith, 1914)

In this connection we may also quote the Atharva-veda hymns (AV. 3.27.1-6), a charm consigning an enemy to the serpents for punishment, in which likewise the six regions are associated with six divine regents and with an equal number of dragons, the names of which are identical with those of Tãittirīya Samhitā

prācī dig agnir adhipatir asito rakșitādityā ișavaḥ | tebhyo namo 'dhipatibhyo namo rakșitṛbhyo nama ișubhyo nama ebhyo astu | yo 'smān dveșți yaṃ vayaṃ dvișmas tam vo jambhe dadhmạ̣ ||1 dakṣiṇā dig indro 'dhipatis tiraścirājī rakșitā pitara iṣavaḥ| tebhyo namo 'dhipatibhyo namo rakșitṛbhyo nama iṣubhyo nama ebhyo astu | yo 'smān dveșți yam vayam dvișmas tam vo jambhe dadhmạ̣ ||2 | pratīcī dig varuṇo 'dhipatị pṛdākū rakṣitānnam ișavạ̣| tebhyo namo 'dhipatibhyo namo rakșitṛbyo nama ișubhyo nama ebhyo astu yo 'smān dveșți yam vayaṃ dvișmas tạ̣ vo jambhe dadhmạ̣ ||3 || udīcī dik somo 'dhipatị svajo rakșitāśanir ișavaḥ | tebhyo namo 'dhipatibhyo namo rakșitṛbhyo nama ișubhyo nama 
ebhyo astu |

yo 'smān dvești yam vayam

dviṣmas tam vo jambhe dadhmạ̣

$\|4\|$

dhruvā dig viṣnur adhipatih

kalmāṣagrīvo rakșitā vīrudha

ișavaḥ|

tebhyo namo 'dhipatibhyo namo

rakșitṛbyo nama ișubhyo nama

ebhyo astu |

yo 'smān dvești yạ̣ vayam

dviṣmas tạ̣ vo jambhe dadhmạ

$\|5\|$

ūrdhvā dig bṛhaspatir adhipatih

śvitro rakṣitā varșam iṣavaḥ |

tebhyo namo 'dhipatibhyo namo

rakșitṛbhyo nama iṣubhyo nama

ebhyo astu |

yo 'smān dveșți yạ̣ vayạ̣

dviṣmas tam vo jambhe dadhmạ

$\|6\|$

Agni is regent of the East, its warder is Asita, the Ādityas are the arrows. Worship to these the regents, these the warders, and to the arrows, yea, to these be worship! Within your jaws we lay the one who hates us and whom we hate.

Indra is regent of the South, its warder Tiraścirāji, and the shafts the Fathers. Worship to these the regents, these the warders, and to the arrows, yea, to these be worship! Within your jaws we lay the one who hates us and whom we hate.

Of the West region Varuna is ruler, Pṛdāku warder, Nourishment the arrows. Worship to these the regents, these the warders, and to the arrows, yea, to these be worship! Within your jaws we lay the one who hates us and whom we hate.

Soma is ruler of the Northern region, Svaja the warder, lightning's flash the arrows.Worship to these the regents, these the warders, and to the arrows, yea, to these be worship! Within your jaws we lay the one who hates us and whom we hate.

Viṣnus is ruler of the firm-set region, Kalmāṣagrīva warder, Plants the arrows. Worship to these the regents, these the warders, and to the arrows, yea, to these be worship! Within your jaws we lay the one who hates us and whom we hate. Brihaspati controls the topmost region, Śvitra is warder, and the Rain the arrows. Worship to these the regents, these the warders, and to the arrows, yea, to these be worship! Within your jaws we lay the one who hates us and whom we hate 


\begin{tabular}{|c|c|c|c|c|}
\hline \multirow[t]{2}{*}{ Direction } & \multicolumn{2}{|c|}{$\begin{array}{c}\text { Täittirīya Samhitāa } \\
\text { (TS. 5.5.10.1-2) }\end{array}$} & \multicolumn{2}{|c|}{$\begin{array}{l}\text { Atharva-veda } \\
\text { (AV. 3.27.1-6) }\end{array}$} \\
\hline & serpents & gods & serpents & gods \\
\hline East & $\begin{array}{l}\text { the black snake } \\
\text { (Asita) }\end{array}$ & Agni & Asita & Agni \\
\hline South & $\begin{array}{l}\text { the scorpion } \\
\text { (Prịāku)* }\end{array}$ & Indra & Tiraścirāji & Indra \\
\hline West & the viper (Svaja) & Soma & Pṛdāku & Varuna \\
\hline North & $\begin{array}{l}\text { the striped snake } \\
\text { (Tiraścirāji) }\end{array}$ & Varuna & Svaja & Soma \\
\hline $\begin{array}{l}\text { Upward } \\
\text { Quarter }\end{array}$ & $\begin{array}{l}\text { the white } \\
\text { (Śvitra) }\end{array}$ & Bṛhaspati & Śvitra & Bṛhaspati \\
\hline $\begin{array}{l}\text { Fixed } \\
\text { Quarter }\end{array}$ & $\begin{array}{c}\text { the spotted } \\
\text { necked snake } \\
\text { (Kalmāṣagrīva) }{ }^{\dagger}\end{array}$ & Yama & Kalmāṣagrīva & Viṣṇu \\
\hline
\end{tabular}

The order in which they are given differs slightly, and Viṣnu as regent of the "fixed" quarter has been replaced by Yama, the King of the Dead. There are only three quarters including eastern, upward and fixed quarter that have the same warders while the others are different in the position of the quarter's protectors but there are similarities in the names of serpents. J.P. Vogel ([1926],

* an adder, viper, snake (M. Monier William, [1872], Reprint. 2002: 647)

** the brown svaja (Maurice Bloomfield, 1897: 647); a viper; a snake that has heads at both ends (M. Monier William, [1872], Reprint. 2002: 1275)

*** striped across (Maurice Bloomfield, 1897: 647); striped across (a serpent) (M. Monier William, [1872], Reprint. 2002: 447)

$\dagger$ having a variegated neck (M. Monier William, [1872], Reprint. 2002: 263)
Repr. 1972: 9-10) suggests that the various quarters of the sky mentioned in the Tãittirīya Samhitā are denoted as the abodes of certain classes of spirits which bear obscure names similar to those used in the Atharva-veda. They indicate the tribes of serpents, of which the dragons of the sky are the overlords.

Although the above charm does not indicate the guardians of directions as divine serpents, they are evident from their names, which to some extent agree with that group of four serpents met with in various passages of the Atharva-veda, such as AV.6.56.1-3, which mention the word 'ahi' meaning " $a$ snake, the serpent of the sky, the demon" (M. Monier William, [1872], Reprint. 2002: 125)

$$
\begin{aligned}
& \text { mā no devā } \\
& \text { ahirvadhītsatokāntsahapurușān | } \\
& \text { samyataṃ na vi șparadvyāttaṃ na saṃ } \\
& \text { yaman namo devajanebhyaḥ ||1\| } \\
& \text { namo’ stvasitāya namas tiraścirājaye | }
\end{aligned}
$$


svajāya babhrave namo namo devajanebhyah $\|2\|$

saṃ te hanmi datā datạ̣ samu te hanvā hanū

saṃ te jihvayā jihvāṃ samvāsnāha āsyam $\|3\|$

"Let not the snake, O gods, slay us with our offspring, with our men ; what is shut together may it not unclose; what is open may it not shut together; homage to the god-people.

Homage be to Asita, homage to Tiraśchirāji, homage to Svaja (and)

Babhru, homage to the god-people.

I smite thy teeth together with tooth, thy (two) jaws together with jaw, thy tongue together with tongue, thy mouth, $\mathrm{O}$ snake, with mouth." (J.P. Vogel, [1926], Reprint. 1972: 8)

The four terms Asita ("black"), Tiraśchirāji ("cross-lined"), Svaja ("adder"), and Babhru ("brown") mentioned in the hymns are commonly explained as denoting certain extant species of snakes. In the Atharvaveda such a group of four is often invoked, although under different names. In AV. 7.56.1, we read of four serpents called Tiraśchirāji, Asita, Prịāku, and Kankkaparvan $^{3}$, In AV. 5.13.5-6, we have

${ }^{3}$ AV. 7.56.1

tiraścirājer asitāt pṛdākoḥ pari saṃbhrtam | first the names Kairāta, Pṛishṇa, Upatrinnya, and Babhru, and subsequently Asita, Taimāta, Babhru, and Apodaka ${ }^{4}$ AV. 10.4.13, gives four similar names, Tiraśchirāji, Pridāku, Śvitra, and Asita ${ }^{5}$, but here they are used in the plural. The four terms Vāsuki, Takșaka, Śankkha and Jatin also appear in the Rāmāyana. (B.C. Sinha, 1978: 46) Thus, the four serpents mentioned under somewhat varying names in the verses quoted were apparently associated with the four quarters of the sky as concluded from the hymns, AV. 3.27.1-6. We can clearly see that the names of beings mentioned in magical spells are snakes. It is especially in the Atharva-veda -where numerous interesting references to snakes occur.

J.P. Vogel ([1926], Reprint. 1972: 9) finds the well-known conception of a group of divinities, here six in number, which are regarded as Dikpālas or guardians of the quarters of the universe. But it will be noted that these Dikpālas have not yet been

${ }^{4}$ AV. 5.13.5-6

tat kañkaparvaṇo vișam iyam vīrud anīnaśat $\|1\|$

kāirāta prína upatṛnya babhra ā me śṛ̣utāsitā alīkāḥ | mā me sakhyuḥ stāmānam api șthātāśrāvayanto ni viṣe ramadhvam $\|5\|$ asitasya tāimātasya babhrorapodakasya ca | sātrāsāhasyāhaṃ manyorava jyāmiva dhanvano vi muñcāmi rathāṃiva $\|6\|$

${ }^{5}$ AV. 10.4 .13

hatās tiraścirājayo nipiștāsaḥ prōākavaḥ | darviṃ karikratạ̣ śvitraṃ darbheșv asitam jahi $\|13\|$ 
stereotyped into the fixed group of four or eight lokapālas of later Hindu mythology.

It can be assumed that animals, especially serpents, have been used as protectors of directions since the Vedic period, while gods are the lords of directions. This is evident from the word "rakșitā" meaning "guarded, protected, saved, preserved, maintained" (M. Monier William, [1872], Reprint. 2002: 125). Serpents also have correlative functions together with gods in "protecting" the devotees and "destroying" the one who does not pay homage to the gods and the warders or the enemy of Brahmin as seen in most of the magical spells in the Atharvaveda. Several of them are charms resorted to in order to avert the danger of snakes. The method followed is twofold. On the one hand, the object is to propitiate the snakedemons and to solicit their protection against their own tribe. On the other hand, charms are wielded against the snakes in order to counteract their magical power, and, if possible, to destroy them. (J.P. Vogel, ([1926], Reprint. 1972: 8)

In Buddhist literature, we meet with a snakecharm or paritta called Khandaparitta or a Ahirājasutta of a very early date. When the lord Buddha knew that a monk bitten by a snake had passed away, he said that this monk would not have died, even if bitten by a snake, if he had been suffused with lovingkindness of mind for the four tribes of serpent-kings (ahirāja-kulāni) as follows: Virüpakkhehi me mettam, mettam Erāpathehi me, Chabyāputtehi me mettam, mettam Kanhägotamakehi ca, "My friendly should be unto the Virupakkhas, the Erāpathas, Chabyāputtas, and the Kaṇhāgotamakas."'(Cullavagga, V, 6; A. ii. 72; Jd. ii. 144-7). There is another story of
Mucalinda, the Nāga king, who sheltered Buddha for seven days against rain and winds by spreading his hood over the Master's head. Many nāgas came from four quarters and helped to shelter the newly awakened Buddha as mentioned in Lalitavistara (B.C. Sinha, 1979: 30).Thus, it can be assumed that the personal names of snake-demons are associated with the four quarters of the sky.

Another interesting parallel is afforded by two later Buddhist texts, the Lalitavistara (LV. 282-284) and the Mahāvastu (Mvu. 3.306-309), both composed in Buddhist Sanskrit. The twenty-fourth chapter of the former work is devoted to the meeting of the Buddha with the two merchants, Trapușa and Bhallika, who offer him his first meal after the enlightenment. The chapter concludes with a benedictory hymn, in which the protection of the four quarters is invoked upon travelling traders. Each quarter is represented by a group of seven nakșatras, by one of the Buddhist lokapālas side by side with one of the following four Brahmanical lokapālas: Sūrya, Yama, Varuna, and Manibhadra, as we can see in the following table: 


\begin{tabular}{|c|c|}
\hline Mahāvastu & Lalitavistara \\
\hline 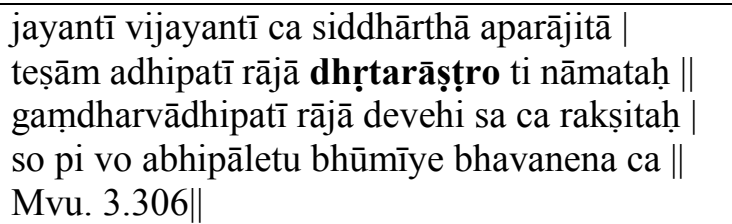 & $\begin{array}{l}\text { teșāṃ cādhipatī rājā dhṛtarāṣțreti viśrutaḥ | } \\
\text { sa sarvagandharvapatih sūryeṇa saha rakṣatu } \\
\text { || LV. 282 }\end{array}$ \\
\hline $\begin{array}{l}\text { tāsām adhipatī rājā virūụhako ti nāmataḥ | } \\
\text { kumbhāṇ̣̂ādhipatī rājā yamena saha rakṣatu || } \\
\text { Mvu. } 3.307 \|\end{array}$ & $\begin{array}{l}\text { teșāṃ cādhipatī rājā virūọhaka iti smṛtaḥ | } \\
\text { sarvakumbhāṇḍādhipatiryamena saha rakṣatu } \\
\text { || LV. } 283 \|\end{array}$ \\
\hline $\begin{array}{l}\text { tāsām adhipatī rājā virūpākṣo ti nāmataḥ | } \\
\text { sa vo nāgādhipo rājā varuṇena saha rakṣatu || } \\
\text { Mvu. } 3.308 \|\end{array}$ & $\begin{array}{l}\text { teșāṃ cādhipatī rājā virūpākṣeti tam viduh | } \\
\text { sa sarvanāgādhipatirvarūṇena saha rakṣatu \| } \\
\text { LV. } 283 \|\end{array}$ \\
\hline $\begin{array}{l}\text { tāsām adhipatī rājā kuvera iti nāmataḥ | } \\
\text { sarvayakșādhipo rājā rākṣasīhi saha rakṣatu \| } \\
\text { Mvu. 3.309 || }\end{array}$ & $\begin{array}{l}\text { teșāṃ cādhipatī rājā kubero naravāhanaḥ | } \\
\text { sarvayakșāṇāmadhipatirmāṇibhadreṇa saha } \\
\text { rakșatu || LV. } 284 \|\end{array}$ \\
\hline
\end{tabular}

J.P. Vogel ([1926], Reprint. 1972: 10) states that the most remarkable point certainly is that the ancient dragons of the quarters have been replaced by the four Mahārājas. Two of the latter, moreover, are designated by names which were originally borne by serpent-kings, as appears in the ancient paritta preserved in the Pali Canon as "Virūpakkha and Erāpatha are not only the names of two Nāgarājas, but in Buddhist mythology they figure also as the lokapalas of the Western and Eastern region respectively."

Virūpakkha is the Cātummahārājikadeva who rules the western quarter and becomes the lord of the Nāgas, and as such he is waited on by the Nāgas regularly and any question of dispute arising among them is referred to him for solution. In the assembly of the devas he sits facing east. Goddess Kālakaṇṇ̄ is his daughter. (J.R. Haldar,
1977: 81) In terms of its etymology, Virūpakkha in Pali consists of two words: virūpa (< vi-rūpa) meaning "deformed, unsightly, ugly" (T.W. Rhys Davids and William Stede, 1921-5: 635) and akkha means "having eyes" (T.W. Rhys Davids and William Stede, 1921-5: 2). As a compound word it means "having deformed eyes", while Virūpakșa in Sanskrit consists of two words: virūpa ( $<$ vi-rūpa), meaning "many coloured, variegated, multiform, manifold various; deformed, misshapen, ugly, unnatural" (M. Monier William, [1872], Reprint. 2002: 984), and akșa, meaning "the eyes" (M. Monier William, [1872], Reprint. 2002: 3). So, Virūpākșa means "diverse eyes; having deformed eyes" (M. Monier William, [1872], Reprint. 2002: 984). According to "Lokapaññatti" composed by Pra Saddhammaghosa, a Burmese monk around the $11^{\text {th }}$ century CE, Virūpakkha Nāgarāja is the lord of serpents and is called "diț̣havisa" which means 
releasing poison from vision or eyes. It means that when Virūpakkha stares at someone, the poison of the serpent can cause the being's death. Making friends with serpents mentioned in Khandaparitta or Ahirājasutta is the process of making friends with the serpent worshippers or Nāga tribes of ancient India. In order to propagate the Buddha's Dharma, the monk needs friendship with local people and should not look down on local beliefs. We can assume that there are various Indian ophiologies among people in the four quarters suggested by the four names of serpents. Therefore, the name of the western lokapāla may represent prior or contemporary indigenous belief in serpent worship or serpent worshippers or Nāga tribes. Greg Bailey and Ian Mabbett (2003: 147) suggest that "the connection between the wandering monk and the ambiguous powers of the forest remains integral to the image and style of the holy man's career."

Virūpakkha is not only mentioned in Buddhist literature as the name of the western lokapāla or tribe of serpent-kings, it is also commonly known in Sanskrit literature and a number of narratives as a name of Lord Śiva (Virūpākșa cf. Virūpacakșus) (M. Monier William, [1872], Reprint. 2002: 984); the elephants of the eastern quarters (din̄-nāga) in the Rāmāyaṇa (Ralph T. H. Griffith, 1870: 52); a Rākșasa who fought on the side of Rāvana against Rāma and Lakṣmaṇa; the Dānavas born to Prajāpati Kaśyapa by his wife Danu; an asura who was the follower of Narakāsura; a Rākșasa who was the friend of Ghatotkaca; a giant who was the friend of a stork called Rājadharma; and one of the eleven Rudra (Vettam Mani, 1998: 862-863).
Dhatarattha is the regent who rules the eastern quarter with his followers, the Gandhabhas. His sons are numerous and are called Inda. He has a daughter named Sirī. (J.R. Haldar, 1977: 81). In terms of its etymology, Dhatarattha in Pali consists of two words: dhata (cf. Skt dhrta) which is the past participle form of dharati meaning "firm, prepared, ready, resolved" (T.W. Rhys Davids and William Stede, 1921-5: 335) and rațtha (cf. Skt rāṣța) meaning "reign, kingdom, empire; country, realm" (T.W. Rhys Davids and William Stede, 1921-5: 562). Dhṛtarāṣțra in Sanskrit consists of two words: dhrita meaning "held, borne, maintained, supported kept, possessed" (M. Monier William, [1872], Reprint. 2002: 519) and rāṣtra. Therefore, Dhatarațtha or Dhṛtarāștra means "whose empire is firm, a powerful king D(M. Monier William, [1872], Reprint. 2002: 519).

J.P. Vogel ([1926], Reprint. 1972: 9) surmised that the name Dhatarattha or Dhṛtarāsțtra has been considered the same as Elāpattra, a tribe of serpent-kings mentioned in paritta, because Elāpattra is known by the name of Dhṛtarāștra Airāvata. In a hymn of the Atharva-veda (AV. 8.10.29), Dhṛtarāșțra Airāvata are mentioned together with Takșaka Vaișāleya side by side as the chief representatives of the serpent race. The name Elāpattra has been recognized as a Prakrit form of the Sanskrit Airāvata (B.C. Sinha, 1979: 47). Hence, it is clearly possible that Dhṛtarāștra and Airāvata, or Elāpattra, are the same serpents, or that Dhṛtarāṣtra descends from the Nāga's progenitor named Airāvata.

It is worthy of note that "Dhṛtarāștra Airāvata" never takes any active part in the 
numerous Nāga stories collected in the Mahābhārata. His name does occur in the Great Epic but he seems to be regarded as a remote ancestor of the Nāga race. B.C. Sinha (1979: 47) assumes that the compilers of the Mahābhārata were not aware of the identity of the two names since Dhrtarāștra and Airāvata, or Elāpattra, are mentioned as a separate Nāga in the list born to the serpent mother Kadrū. Dhṛtrāștra mentioned in the Mahābhārata is a serpent born to Kaśyapa Prajāpati by his wife Kadrū. Dhṛtarāștra is also the name of one of the famous sons of Vāsuki and the keeper of jewels Mṛtasañjīvinī (Vettam Mani, 1998: 862863), while Elāpattra figures here as the most wise Nāga, who knows what will happen in the future after the serpent mother Kadrū has pronounced her curse. It is an interesting point to observe that Elāpattra does not play a prominent part in the Brāhmanical tradition but he has a remarkable career in the Buddhist tradition. It is said that Elāpattra had been born as a Nāga because in a previous birth he had destroyed an elā tree. The legend further relates that Elāpattra came from Taxilā to the Deer Park to pay respects to the Buddha according to the Mahāvastu (B.C. Sinha, 1979: 102-104). The Chinese pilgrim Xuanzang mentions Elāpattra among the three great Nāga kings who obtained a share of the Buddha's relics. On his way to Taxilā he saw that place which was supposed to be the abode of the Nāga. Alexander Cunningham identified the sacred lands of Elāpattra as a small reservoir of clear water not far from Hasan-Abdāl, about ten miles to the north-west of Shah Dheri. Although no longer associated with the Nāga king, the tank is still held in reverence by Sikhs and Muslims. From Xuanzang we learn that
Elāpattra was worshipped as a regent of the water and as the giver of rain. From his account it is clear that the tank of the Nāga Elāpattra was situated at some distance to the north-west of Taxilā (B.C. Sinha, (1979: 47-48). Dhatarattha is also mentioned as the Nāga king in the Mahāsamaya sutta. It can be assumed that this name is the name of a significant serpent. If we agree with J.P. Vogel, there is some relationship between Dhatarațtha Nāgarāja and Erāpatha (or Elāpattra) as the same serpent family which are elevated to be the eastern lokapāla, so the name of the eastern lokapāla may represent serpent worshippers or Nāga tribes in early Buddhism.

J.P. Vogel ([1926], Reprint. 1972: 10) states that the most remarkable point certainly is that here the ancient dragons of the quarters have been replaced by the four Mahārājas. Two of the latter, Virūpakkha and Dhataratțha, moreover, are designated by names which were originally borne by serpent-kings, Virūpakkha and Erāpatha, as appears from the ancient paritta preserved in the Pali Canon. I agree with Vogel's idea in part but there are some specific arguments to be taken in to account. Firstly, the serpents mentioned in the paritta are not specified clearly as serpents of the directions; nonetheless, serpents have played an important role as protectors of the directions since the Vedic period. The ancient dragons of the quarters have been replaced by popular gods worshipped by Aryan people as we can see in early magical spells in which serpents were mentioned with lords of direction as protectors. This expresses an Aryan acceptance of indigenous beliefs but later gods were mentioned independently as 
Digadhipati which shows indigenous beliefs had already been integrated.

However, Bandula Jayawardhana (19791989: 566) states that Dhatarattha of the cātummahārājika is not to be confused with the king of that name who was ruler of the Nāga world. In the Mahāsamaya sutta this is made clear by the latter's separate arrival at the great concourse. That nāga king arrives much later, in the company of the nāgas of Yamunā. If the eastern lokapāla has its origin in serpent worship or the Nāga tribes, there is some question as to why Dhatarattha is the lord of the gandhabbas.

According to O. H. de A. Wijesekera (1994: 191-192), Dhataratțha (D, II.257), is a name which undoubtedly echoes Varuna's accredited rulership over the gandharvas in the Satapatha Brāhmana (ŚBr. 13.4.3.7-8) ${ }^{6}$. The gandharvas are said

\footnotetext{
${ }^{6}$ ŚBr. 13.4.3.7-8

atha tritiye'han

evamevaitāsviștișu

samsthitāsveșaivāvrụdadhvarya

viti havai

hotarityevādhvaryurvaruna

ādityo rājetyāha tasya

gandharvā viśasta ima āsata iti

yuvānaḥ śobhanā upasametā

bhavanti

tānupadiśatyatharvāṇo vedaḥ

so'yamityatharvaṇāmekam

parva vyācakșāṇa

ivānudravedevamevādhvaryuḥ

sampreșyati na

prakramānjuhoti

atha caturthe'han

evamevaitāsviștiṣu

samsthitāsveșaivāvṛdadhvarya

viti havai

hotarityevādhvaryuh somo
}

to have Varuna (Āditya) as their ruler and Soma becomes the ruling deity over the apsarās. The Mahābhārata represents Varuṇa as a deva-gandharva. This is not surprising as Varuna is given the overlordship of the waters in the Rgveda (RV. 7. 64. 2) ${ }^{7}$ itself, and as the Atharva-veda (AV. 11.7.27, 9.16; 14.2.9) ${ }^{8}$ clearly shows, the gandharvas and the apsarās are only the male and female aspects of a single concept that relates to water. Dhrta-vrata occurring in the Rgveda half a dozen times as an epithet of Varuna can easily be the antecedent of the Pali Dhataratțha (Dhṛtarāṣtra), Varuṇa being in the Rgveda described as 'universal monarch' (samrāj) with the attribute of sovereign (kșatra) preeminently bestowed on him. Both "rāșțra" and "samrāj" are derived from $V_{\text {raj }}$ meaning 'rule,' which may semantically approximate to vrata, law or ordinance (O. H. de A. Wijesekera 1994: 208). I agree with O. H. de A. Wijesekera that Varuna has some connection with Gandhabbas, but the name "Dhataratṭha"

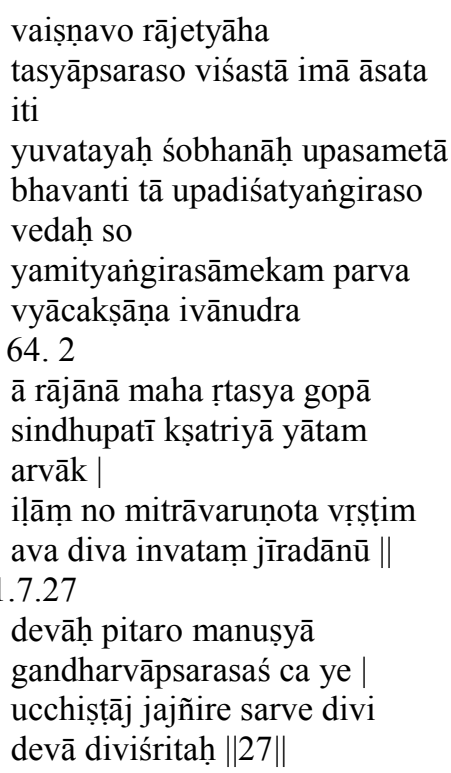


being derived from an epithet of Varuna is unreliable because "Dhṛta-vrata meaning "maintaining law or order" has a different meaning from the Pali Dhatarattha (Dhṛtarāstra). Another possible theory is that Dhatarattha and Indra, or Sakka, in Buddhist literature may be the same person. In the Vidhurapanditita Jātaka (J.V. p. 260), Sakka is referred to as Gandhabba-rāja, king of Gandhabba; moreover, the relationship between Indra and the gandhabbas such as Mātali, or Pañcasikha is often mentioned in Buddhist texts.

Dhatarattha is not only mentioned as the name of the eastern lokapāla or tribe of serpent-kings in Buddhist literature, this name has also been commonly recognized in Sanskrit literature as the name of a deva gandharva (Semi-god) who was the son of the hermit Kaśyapa and Muni, took part in the birth-celebration of Arjuna and went to the presence of King Marutta as a messenger of Indra. This Gandarva was born as Dhrtarāștra, the father of Duryodhana; a king who was the son of Janamejaya and the grandson of Kuru, a king of the Lunar dynasty (Vettam Mani, 1998: 237); a son of the Daitya Bali; a king of kāśî (M. Monier William, [1872], Reprint. 2002: 519).

As we can see, Dhrtarāṣtra has been mentioned in Sanskrit literature since the Vedic period and appeared more frequently in the Itihāsa-Purāna. It has also been recognized in Buddhist literature. Both literary works use this name for people, animals, and places. Buddhism adopts this earlier well-known name as the name of the lord of the eastern direction particularly. This may show an acceptance of indigenous beliefs, by using an earlier name which connects with the indigenous belief of serpent worship, the name of gods, gandhabba and the characters in the Mahābhärata as the name of the ruler of the eastern quarter and the King of Gandhabbas in Buddhist literature.

Virūlha, or Virūlhaka, is one of the Regents who rules the southern quarter, and, in the assembly of the devas, sits facing north. His followers are the Kumbhandas. (J.R. Haldar, 1977: 80-81) This name appears particularly in Buddhist literature. According to M. Monier-William ([1872], Reprint. 2002: 984), Virūḍhaka means "grain that has begun to sprout; a prince of the kumbhandas; a lokapala in Buddhist literature; a son of Prasenajit". All given meanings were found only in Buddhist contexts and not in mainstream Sanskrit literature. In terms of etymology, viruh (vi- $\sqrt{ }$ ruh) means "to grow out, shoot forth, sprout sprouted" and virūtha means "sprouted, come forth, born, arisen" (M. Monier-William, [1872], Reprint. 2002: 984) while virūlha in Pali is the past participle form of the virūlhati meaning "having grown, growing" (S. ii.65; T.W. Rhys Davids and William Stede, 1921-5: 635).

Kumbhandas are the retinue of Virūḷaka, for which both Pāli and Sanskrit sources offer an inadequate explanation of the derivation. It is quite possible that this term "Kumbhanda" was borrowed from either the Dravidian or the Mundia languages, as these were the two other major linguistic groups besides the Indo-Aryan group that could have been known to the Gangetic peoples. M.M.J. Marasinghe (1974: 235) states that although in the Dravidian languages the 
word is not found in its present form, the components of the word in most Dravidian languages seem to suggest some associations with the origins of spirit belief itself.

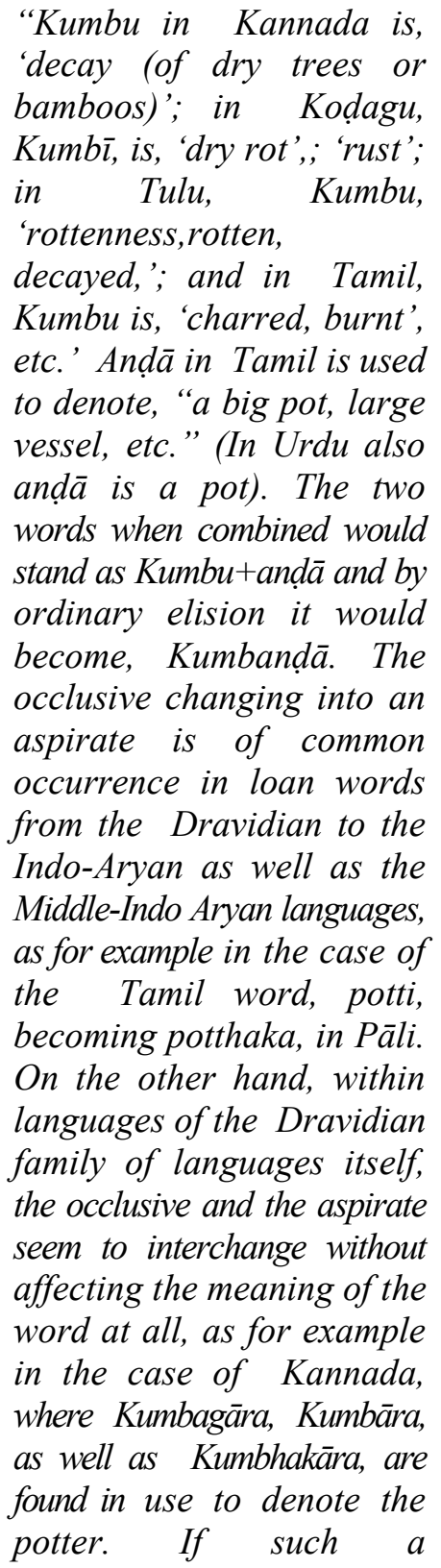

\begin{abstract}
composition of the word is not too fanciful a suggestion, it could have meant at an early stage of its usage, 'rotten in the pot, decayed in the pot, etc.' The word Kumbu-nāttam is explained by the Madras Tamil Lexicon as the smell of the decayed', thus showing the associations of the word in this sense" (M.M.J. Marasinghe, 1974: 235).
\end{abstract}

In a non-advanced cultural atmosphere, where urn-burials were quite common, with the idea of rebirth, such an idea of the spirit of the dead person rising out of the urn in which his/her last remains had been deposited is not impossible. Fairly recent archaeological excavations demonstrate that urn-burials were common in most parts of India, at one stage or the other in their cultural histories. Of special interest to us are the megalithic findings in the Deccan, and Orissan regions, and more particularly the evidence collected by Davids Roy on the megalithic monuments among the Khāsīs almost in the very heart of the area which received Buddhist influence (M.M.J. Marasinghe, 1974: 237).

Thus, it is possible that the meaning of the name Virūḷha, or Virūlhaka, "to grow out, shoot forth, sprout, sprouted," may be a trace of earlier or contemporaneous indigenous beliefs, as seen in the word kumbhandia which might stem from the ancient practice of urn-burial and the belief that the soul or spirit of the dead could rise from its grave (in this case the urn). The 
word Kumbhanda originally used to describe the dead person could have come to be used for the spirit of the dead in course of time (M.M.J. Marasinghe, 1974: 237). Moreover, the concept of death also connects with the southern quarter of which Virū lha is the lord according to Buddhist literature, and Yama is the lord in Sanskrit literature. Thus, the name of the Southern lokapāla may reflect the Buddhist acceptance of indigenous beliefs, as well.

\section{Conclusion}

The study suggests that the names of three of the Great Kings - Dhataratțha, Virūḷha or Virūḷhaka, and Virūpakkha - may be relics or indications of earlier or contemporaneous indigenous beliefs and peoples who had cultural encounters with Buddhism. The indigenous beliefs and social groups consist of the nāga cult, belief in spirits, the early practice of urn-burials, and belief in the soul or spirit of the dead rising out of the grave, and nāga as a tribal people. Buddhism tried to incorporate these beliefs from some of these social groups into its cosmology by elevating some local gods, indigenous beliefs and tribal peoples to divine status, such as the lokapālas, who become chieftains of the gandhabbas, the nāgas and the kumbhandas in order to exploit earlier or contemporaneous indigenous beliefs.

\section{References}

Bailey, Greg and Ian Mabbett. 2003. The sociology of early Buddhism. Cambridge: Cambridge University Press.

Davids, T. W. Rhys and Stede, William. 1921-5. The Pali Text Society's Pali-
English Dictionary, London: the Pali Text Society.

Haldar, J. R. 1977. Early Buddhist Mythology. New Delhi: Manohar. Hymns of the Atharva-Veda (The Sacred Books of the East, Vol. 42). 1897. Translated by Maurice Bloomfield. Delhi: Motilal Banarsidass.

Jayawardhana, Bandula. Cātummahārājika. 1971. Encyclopedia of Buddhism 3: 707708.

Jayawardhana, Bandula. Dhatarattha. 19791989. Encyclopedia of Buddhism 4 : 565566

Malalasekera, G. P. [1938], Reprint. 2007. Dictionary of Pāli Proper Names. 2 vols. Delhi: Motilal Banarsidass.

Mani, Vettam. 1998. The Purānic Encyclopaedia: a comprehensive dictionary with special reference to the epic and Purānic literature. Delhi: Motilal Banarsidass.

Marasinghe, M. M. J. 1974. Gods in Early Buddhism: a study in their social and mythological milieu as depicted in the Nikāyas of the Pāli Canon. Kelaniya: University of Sir Lanka, Vidyalankara Campus

Monier-Williams, M. [1872], Reprint. 2002. A Sanskrit-English Dictionary. Delhi: Motilal Banarsidass.

Sinha, B. C. c1978. Serpent Worship in Ancient India New Delhi : Books Today. 
MANUSYA: Journal of Humanities Regular 19.1, 2016

The Artharvaveda: Sanskrit text with

English translation. 1997. Translated by

Devi Chand. Delhi: Munshiram

Manoharlal, The Yajurveda (Täittirīya

Samhitā). Translated by A. B. Keith

(1914) October 1, 2014

$<$ http://www.sacred-

texts.com/hin/yv/index.htm>.

Valmiki. 1870-1874. The Ramayana of

Valmiki. Translated by Ralph T. H.

Griffith. London: Trubner.

Vogel, J .P. [1926], Reprint. 1972. Indian

Serpent-lore: Or, The Nāgas in Hindu

Legend and Art. Varanasi: Prithivi

Prakashan.

Wijesekera, O. H. de A. 1994. Vedic

Gandharva and Pali Gandhabba. In

Buddhist and Vedic Studies A Miscellany,

pp.175-212. Delhi: Motilal Banarsidass

Publishers 